\author{
MARLENA PODLECKA* \\ Warszawa, Polska \\ ORCID ID: https://orcid.org/oooo-0oo2-2213-374X \\ KASPER SIPOWICZ** \\ Warszawa, Polska \\ ORCID ID: https://orcid.org/oooo-ooo1-7384-2899 \\ TADEUSZ PIETRAS*** \\ Warszawa, Polska \\ ORCID ID: https://orcid.org/oooo-ooo3-1771-3819
}

\title{
ZNACZENIE KONCEPCJI NEURORÓŻNORODNOŚCI DLA AUTORSTWA ŻYCIA OSÓB ZE SPEKTRUM AUTYZMU
}

Streszczenie: Przedmiotem badania jest refleksja nad fenomenem neuroróżnorodności u osób ze spektrum ASD w kontekście koncepcji autorstwa własnego życia. Neuroróżnorodność oznacza zróżnicowanie populacyjne właściwości ośrodkowego układu nerwowego, przekładające się na zróżnicowanie poznawcze i emocjonalne populacji. Celem pracy jest przegląd literatury na temat związku, jaki zachodzi między autorstwem własnego życia, neuroróżnorodnością a zaburzeniami ze spektrum ASD. Zastosowaną metodą w niniejszej pracy jest przegląd literatury ze szczególnym uwzględnieniem literatury polskojęzycznej. Obraz kliniczny spektrum ASD jest zróżnicowany. Wśród osób z ASD są zarówno osoby samodzielne, jak i wymagające całodobowego nadzoru. Mówi się o autyzmie dobrze i źle funkcjonującym. Osoby z autyzmem dobrze funkcjonującym są zdolne do samostanowienia o sobie w przeciwieństwie do osób źle funkcjonujących, które wymagają opieki i wsparcia środowiskowego. Wśród osób z ASD istnieje duża

\footnotetext{
* Mgr Marlena Podlecka, Klinika Nerwic, Zaburzeń Osobowości i Odżywiania, Instytut Psychiatrii i Neurologii w Warszawie; e-mail: mpodlecka@ipin.edu.pl.

** Dr Kasper Sipowicz, Akademia Pedagogiki Specjalnej im. M. Grzegorzewskiej w Warszawie, Katedra Interdyscyplinarnych Studiów nad Niepełnosprawnością; e-mail: ksipowicz@aps.edu.pl.

*** Dr hab. n. med. Tadeusz Pietras, II Klinika Psychiatryczna, Instytut Psychiatrii i Neurologii wWarszawie; e-mail: tpietras@ipin.edu.pl.
} 
neuroróżnorodność obrazu klinicznego. Znaczna część osób jest zdolna do samostanowienia i kreowania własnego życia.

Słowa kluczowe: autyzm; neuroróżnorodność; autorstwo własnego życia osoby $\mathrm{z}$ niepełnosprawnością.

\section{Wstęp}

Autyzm uznaje się za jedno z najbardziej tajemniczych, a równocześnie intrygujących zaburzeń rozwoju człowieka. W związku z rzekomą „epidemią autyzmu”, która wbrew obiegowym przeświadczeniom jest kwestią wątpliwą (Pisula 2018), odnotowuje się wciąż rosnące zainteresowanie opinii publicznej tym zaburzeniem. Fenomen autyzmu porzucił niejako pierwotny obszar swej nozologicznej genezy, a zatem psychiatrię oraz psychologię, i rozpoczął ekspansję ku dyskursowi osadzonemu w przestrzeni publicznej i kulturze popularnej. Zainteresowanie autyzmem, jako jednym z nielicznych spośród szerokiego wachlarza chorób i zaburzeń psychicznych, przekroczyło granice nauki i systemu leczenia, wytyczając zarazem całkowicie nowy kierunek rozumienia owego fenomenu. Neuroróżnorodność w autyzmie ma ważne znaczenie dla współczesnej pedagogiki, gdyż wpisuje się w jej humanistyczny paradygmat (Krause 2010). Odejście od pojęcia patologii na rzecz neuroróżnorodności uzasadnia równe traktowanie różnych grup osób, co konstytuuje inkluzyjny model nauczania (Sipowicz, Pietras 2017). Celem niniejszej publikacji jest refleksja nad związkiem, jaki zachodzi pomiędzy takimi pojęciami, jak autyzm, autorstwo własnego życia i neuroróżnorodność. Pojęcia te są często używane w dyskursie współczesnej pedagogiki specjalnej, reprezentują jednak różne podejścia. Termin autyzm pochodzi z psychiatrii, autorstwo własnego życia z nurtu demedykalizacji pedagogiki specjalnej, a pojęcie neuroróżnorodność pochodzi z koncepcji antydyskryminacyjnych w pedagogice i medycynie.

\section{Autyzm - klasyfikacja i kryteria diagnostyczne ICD-10}

Międzynarodowe systemy klasyfikacyjne zapewniają społeczeństwu mylne, aczkolwiek kojące przeświadczenie, iż nauka w XXI potrafi rzetelnie określić definicyjne ramy całościowych zaburzeń rozwoju oraz przedstawić trafne kryteria diagnozowania (Verhoeff 2012). Chociaż autyzm jako jednostka nozologiczna wyodrębniony został już ponad 7o lat temu, to nadal nie potrafimy w pełni określić jego istoty.

Kryteria rozpoznawania autyzmu opisane w międzynarodowych klasyfikacjach (tab. 1) uznać należy za pewnego rodzaju kompromis definicyjny. Już sama zmienność kryteriów rozpoznawania oraz sposobów klasyfikowania tego zaburzenia w kolejnych rewizjach ICD oraz DSM dowodzi pewnej nieuchwytności autyzmu jako pozycji nozologicznej. Jak bowiem rozumieć przesuwanie się na przestrzeni lat granic rozpoznawania autyzmu? Poszukując odpowiedzi na te pytanie, uwzględnić 
należy przede wszystkim rozwój wiedzy pochodzącej z badań naukowych oraz zmienność interpretacji pewnych aspektów.

Tabela 1. Kryteria diagnozowania autyzmu wg ICD-10

\begin{tabular}{|c|c|}
\hline \multirow[t]{4}{*}{ A } & $\begin{array}{l}\text { Nieprawidłowy rozwój widoczny przed trzecim rokiem życia w co najmniej jednym } \\
\text { z następujących obszarów: }\end{array}$ \\
\hline & 1) rozumienia i ekspresji językowej, \\
\hline & 2) rozwoju wybiórczego przywiązania społecznego lub wzajemnych kontaktów, \\
\hline & 3) funkcjonalnej lub symbolicznej zabawie. \\
\hline \multirow[t]{4}{*}{ B } & $\begin{array}{l}\text { Co najmniej sześć objawów spośród wymienionych w punktach } 1,2 \text { i 3, przy czym co } \\
\text { najmniej dwa z pozycji } 1 \text { i po co najmniej jednym z pozycji } 2 \text { i 3: }\end{array}$ \\
\hline & $\begin{array}{l}\text { 1) jakościowe nieprawidłowości w kontaktach społecznych: } \\
\text { a) niedostateczne wykorzystywanie kontaktu wzrokowego, wyrazu twarzy, postawy, } \\
\text { gestów w kontaktach społecznych, } \\
\text { b) niedostateczny rozwój związków rówieśniczych, } \\
\text { c) brak odwzajemnienia społeczno-emocjonalnego, przejawiający się brakiem lub } \\
\text { odmiennością reagowania na emocje innych osób, brakiem modulacji zachowania do } \\
\text { społecznego kontekstu albo słaba integracja zachowań społecznych, emocjonalnych } \\
\text { i komunikacyjnych, } \\
\text { d) brak spontanicznej potrzeby dzielenia z innymi radości, zainteresowań lub } \\
\text { osiągnięć. }\end{array}$ \\
\hline & $\begin{array}{l}\text { 2) jakościowe nieprawidłowości w komunikowaniu się: } \\
\text { a) opóźnienie lub brak rozwoju mówionego języka, bez próby kompensowania za } \\
\text { pomocą gestów lub mimiki, } \\
\text { b) niedostatek inicjatywy i wytrwałości w podejmowaniu konwersacji, w której zacho- } \\
\text { dzą zwrotne informacje na komunikaty innej osoby, } \\
\text { c) stereotypowe i powtarzające się idiosynkratyczne wykorzystanie słów i wyrażeń, } \\
\text { d) brak spontanicznej różnorodności zabaw imitujących role społeczne. }\end{array}$ \\
\hline & $\begin{array}{l}\text { 3) ograniczone, powtarzające się i stereotypowe wzorce zachowań, zainteresowań } \\
\text { i aktywności: } \\
\text { a) pochłonięcie jednym lub kilkoma stereotypowymi zainteresowaniami o nieprawid- } \\
\text { łowej treści, } \\
\text { b) wyraźnie kompulsywne przywiązanie do specyficznych niefunkcjonalnych czynno- } \\
\text { ści oraz ich zrytualizowanie, } \\
\text { c) stereotypowe, powtarzające się manieryzmy ruchowe, obejmujące stukanie, kręcenie } \\
\text { palcami albo złożone ruchy całego ciała, } \\
\text { d) koncentracja na cząstkowych lub nieistotnych właściwościach przedmiotów służą- } \\
\text { cych do zabawy (takich jak: zapach, struktura powierzchni, powodowanie hałasu lub } \\
\text { wibracji). }\end{array}$ \\
\hline $\mathrm{C}$ & $\begin{array}{l}\text { Obrazu klinicznego nie można wyjaśnić innymi odmianami całościowych zaburzeń, } \\
\text { specyficznymi rozwojowymi zaburzeniami rozumienia języka, wtórnymi trud- } \\
\text { nościami społeczno-emocjonalnymi, reaktywnymi i selektywnymi zaburzeniami } \\
\text { przywiązania, upośledzeniem umysłowym z cechami zaburzeń emocji i zachowania, } \\
\text { schizofrenią o bardzo wczesnym początku oraz zespołem Retta. }\end{array}$ \\
\hline
\end{tabular}

Źródło: Rajewski 2011, s. 592-593. 
Należy rozumieć, iż niezależnie od kierunku naukowego dyskursu i związanej z nim tendencyjności/subiektywności w określaniu tego, czym w swej istocie jest autyzm, istnieje uniwersum losów ludzkich, wśród których nieprawidłowości w obszarze interakcji społecznych, komunikowania się oraz występowanie ograniczonych wzorców zachowań, zainteresowań i aktywności (Posyła 2018) przyczyniają się do realnego cierpienia tychże osób, bez względu na przyporządkowaną im nozologiczną etykietę. Możliwie rzetelne kryteria diagnostyczne, choć przypuszczalnie już w samych swych założeniach niepozbawione błędu, umożliwiają dobór odpowiedniej formy terapii oraz udzielenie adekwatnego wsparcia w systemie społecznym.

Specyficzny wzorzec funkcjonowania osób w spektrum autyzmu, czyli tzw. triada autystyczna, jest bezpośrednią konsekwencją nieprawidłowego rozwoju i działania układu nerwowego (Wujcik i in. 2010). Poszczególne mechanizmy etiopatopatogenezy nie zostały jednak jak dotąd poznane. Co więcej, liczne badania wskazują na efekt ekwifinalności i ekwiwalentności (Grandin 2017), krystalizując tym samym niezwykłą heterogeniczność behawioralną i neuorologiczną oraz niepowtarzalność zmian genetycznych tychże osób. Jak wspomina Steve Silberman (2017, s. 22), „jeśli spotkałeś jedną osobę z autyzmem, znasz jeden przypadek autyzmu”. Rozumiejąc zatem, iż obiektywną podstawą konstruowania odrębnej jednostki nozologicznej jest wspólny obraz kliniczny poszczególnych przypadków, należy zadać podstawowe dla dalszych rozważań pytanie: czy możemy mówić o jednym wspólnym zaburzeniu? Wydawać się może, iż opracowana w 1979 roku przez Lornę Wing (Pisula 2018) koncepcja spektrum w wystarczającym stopniu uwzględnia i opisuje zróżnicowane nasilenie objawów, zbliżając się do jak najpełniejszego ujęcia fenomenu autyzmu. Cóż jednak, jeśli swoistej reinterpretacji poddamy nie sposób opisywania i klasyfikowania poszczególnych objawów, a samą zasadność uznawania ich za objawy? W publikacji nie odnosimy się do klasyfikacji DSM-5 i ICD-11, gdyż żadna $z$ nich nie obowiązuje w polskim systemie prawnym. Obie klasyfikacje zestawiamy w poniższej tabeli.

Tabela 2a. Kryteria spektrum autyzmu wg kryteriów DSM-5

\footnotetext{
Kryteria spektrum autyzmu wg klasyfikacji DSM-5 299.00 (F 84.0)

Następujące trudności w komunikacji społecznej i w zakresie interakcji społecznych w wielu kontekstach, manifestujące się obecnie lub w wywiadach, w następujący sposób (przykłady stanowią ilustrację i nie wyczerpują tematu):

Deficyt w sferze okazywania społeczno-emocjonalnej wzajemności, w zakresie od nieprawidłowych stosunków towarzyskich i niezdolności w prowadzeniu normalnej rozmowy, przez ograniczone reagowanie na zainteresowanie, uczucia lub oddziaływanie, aż do niezdolności zapoczątkowania lub opowiadania na jakiekolwiek interakcje.

Deficyt w sferze komunikacji niewerbalnej, w zakresie od słabo zintegrowanego przekazu werbalnego i niewerbalnego, przez nieprawidłowości w nawiązywanie kontaktu wzrokowego, w języku ciała lub ograniczeń w rozumieniu i używaniu gestów, aż do całkowitego braku mimiki i zaniku przekazu niewerbalnego.
} 
Deficyt w obszarze rozpoczynania, podtrzymywania i rozumienia relacji, w zakresie od trudności w dostosowania zachowań do różnych kontekstów społecznych, przez trudności w zabawie opierającej się na wyobraźni lub w nawiązywaniu przyjaźni, aż do całkowitego braku zainteresowania rówieśnikami.

Należy uwzględnić aktualne uszczegółowienie ciężkości:

Określenie ciężkości zaburzenia ustala się na podstawie stopnia upośledzenia komunikacji społecznej oraz ograniczonych, powtarzających się wzorców zachowań.

Powtarzające się wzorce zachowań, zainteresowań lub czynności, manifestujące się obecnie lub w wywiadach przynajmniej dwoma spośród wymienionych (przykłady stanowią ilustrację i nie wyczerpują tematu):

Stereotypowe lub stale powtarzane manieryzmy ruchowe, użycie przedmiotów lub elementów mowy (np. proste stereotypie ruchowe, ustawianie zabawek w szeregu lub przewracanie przedmiotów, echolalia, używanie dziwacznych, znanych jedynie sobie wyrażeń).

Potrzeba niezmienności, przywiązanie do czynności rutynowych lub wzorców zachowań werbalnych bądź niewerbalnych, przybierających formę rytuału (np. niezwykle silna reakcja stresowa na niewielką zmianę, trudność w akceptowaniu zmian, sztywne wzorce myślenia, rytuały powitalne, potrzeba chodzenia tą samą trasą lub jedzenia tych samych rzeczy każdego dnia).

Niezwykle ograniczone zainteresowania o szczególnej intensywności (np. silne przywiązanie do nietypowych przedmiotów lub całkowite zaabsorbowanie uwagi tymi przedmiotami, przesadnie zdefiniowane lub nieprzemijające zainteresowania).

Wzmożona lub osłabiona reaktywność na bodźce czuciowe lub niezwykłe zainteresowanie zmysłowymi aspektami otoczenia (np. wyraźna obojętność na ból/temperaturę, niechęć do określonych dźwięków lub faktur, nadmierne wąchanie lub dotykanie przedmiotów, zafascynowanie światłem lub ruchem).

Należy uwzględnić aktualne uszczegółowienie ciężkości:

Określenie ciężkości zaburzenia ustala się na podstawie stopnia upośledzenia komunikacji społecznej oraz ograniczonych, powtarzających się wzorców zachowań.

Początek objawów przypada na wczesny okres rozwoju (deficyty mogą nie ujawniać się w pełni, póki wymogi społeczne nie przekroczą ograniczonych umiejętności lub w przypadku maskowania przez inne wyuczone w późniejszym życiu strategie).

Objawy powodują znaczące kliniczne upośledzenie funkcjonowania w sferze społecznej, zawodowej i innych.

Występowanie tych zakłóceń nie może być lepiej wyjaśnione poprzez rozpoznanie niepełnosprawności intelektualnej( zaburzenia rozwoju intelektualnego) lub całościowego opóźnienia rozwoju. Niepełnosprawność intelektualna i zaburzenia należące do spektrum autyzmu często współwystępują jednocześnie. Aby móc rozpoznać jednoczesne występowanie zaburzenia, należącego do spektrum autyzmu oraz niepełnosprawności intelektualnej, umiejętność komunikacji powinna pozostawać na poziomie niższym niż ogólny poziom rozwoju.

Uwaga: Osoby z dobrze udokumentowanym, na podstawie kryteriów DSM-IV, rozpoznaniem zaburzenia autystycznego, zaburzenia Aspergera lub całościowego zaburzenia rozwojowego nieokreślonego inaczej powinny mieć przypisywane rozpoznanie zaburzenia należące do spektrum autyzmu. U osób, u których występują wyraźne deficyty w zakresie komunikacji, jednak objawy nie spełniają kryteriów rozpoznania zaburzenia należącego do spektrum autyzmu, należy przeprowadzić ocenę w kierunku występowania zaburzenia w komunikacji społecznej. 


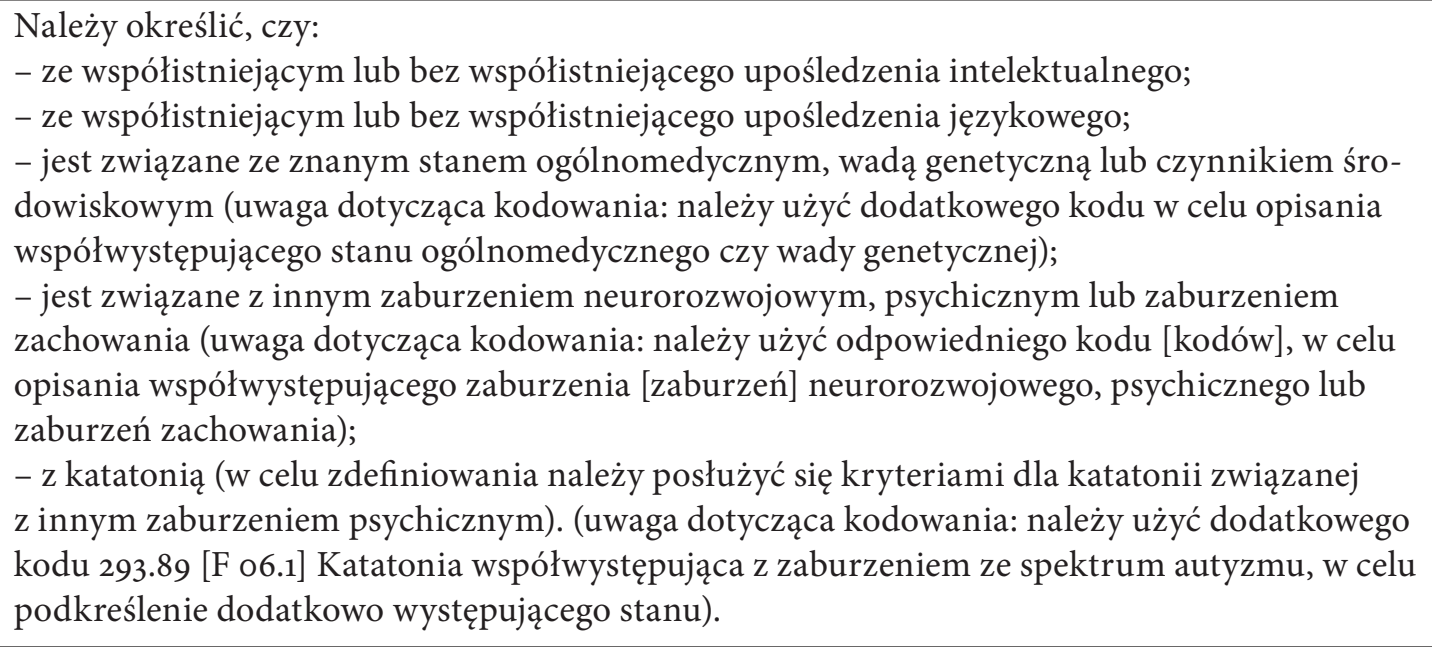

Tabela $2 b$

\begin{tabular}{|c|c|c|}
\hline \multicolumn{3}{|c|}{ Poziomy ciężkości zaburzenia należące do spektrum autyzmu } \\
\hline Poziom ciężkości & Komunikacja & $\begin{array}{c}\text { Ograniczone, powtarzane } \\
\text { zachowania }\end{array}$ \\
\hline $\begin{array}{l}\text { Poziom } 3 . \\
\text { „wymagający bardzo } \\
\text { znacznego wsparcia” }\end{array}$ & $\begin{array}{l}\text { Znaczne deficyty w zakresie komu- } \\
\text { nikacji werbalnej i niewerbalnej, } \\
\text { powodujące poważne upośledzenie } \\
\text { funkcjonowania, bardzo wyraźne ogra- } \\
\text { niczenie w zakresie inicjowania kon- } \\
\text { taktów międzyludzkich i minimalna } \\
\text { zdolność odpowiadania na starania } \\
\text { innych osób, prowadzące do nawią- } \\
\text { zania interakcji. Przykładowo: osoba } \\
\text { posługująca się kilkoma zrozumiałymi } \\
\text { słowami, rzadko nawiązująca kontakt, } \\
\text { czasem jedynie w celu zaspokojenia po- } \\
\text { trzeb i reagująca wyłącznie na bardzo } \\
\text { bezpośrednie komunikaty. }\end{array}$ & $\begin{array}{l}\text { Sztywność wzorców zacho- } \\
\text { wań, niezwykła trudność } \\
\text { w radzeniu sobie ze zmia- } \\
\text { nami lub inne ograniczone/ } \\
\text { powtarzane zachowania, } \\
\text { wyraźnie wpływające na } \\
\text { funkcjonowanie w wielu } \\
\text { obszarach. Znaczne cierpie- } \\
\text { nie/trudności, pojawiające } \\
\text { się w chwili zmieniania } \\
\text { obiektu zainteresowań lub } \\
\text { aktywności. }\end{array}$ \\
\hline $\begin{array}{l}\text { Poziom } 2 . \\
\text { „wymagający znacz- } \\
\text { nego wsparcia” }\end{array}$ & $\begin{array}{l}\text { Widoczne deficyty w zakresie ko- } \\
\text { munikacji werbalnej i niewerbal- } \\
\text { nej. Upośledzenie funkcjonowania } \\
\text { społecznego, pomimo wsparcia. } \\
\text { Ograniczona zdolność inicjowania } \\
\text { interakcji społecznych. Zmniejszona } \\
\text { lub odmienna zdolność odpowiadania } \\
\text { na starania innych osób. Przykładowo: } \\
\text { osoba porozumiewająca się za pomocą } \\
\text { prostych zdań, której interakcje ze } \\
\text { środowiskiem ograniczają się do wą- } \\
\text { skiego obszaru zainteresowań i która } \\
\text { posługuje się komunikacją niewerbalną } \\
\text { w dziwaczny sposób. }\end{array}$ & $\begin{array}{l}\text { Sztywność wzorców zacho- } \\
\text { wań, trudności w radzeniu } \\
\text { sobie ze zmianami lub } \\
\text { ograniczone/powtarzane } \\
\text { zachowania występujące } \\
\text { z zauważalną częstością } \\
\text { i wpływające na funkcjono- } \\
\text { wanie w rozmaitych sytua- } \\
\text { cjach. Cierpienie/trudności, } \\
\text { pojawiające się w chwili } \\
\text { zmiany obiektu zaintereso- } \\
\text { wania lub aktywności. }\end{array}$ \\
\hline
\end{tabular}




\begin{tabular}{|c|c|c|}
\hline \multicolumn{3}{|c|}{ Poziomy ciężkości zaburzenia należące do spektrum autyzmu } \\
\hline Poziom ciężkości & Komunikacja & $\begin{array}{c}\text { Ograniczone, powtarzane } \\
\text { zachowania }\end{array}$ \\
\hline $\begin{array}{l}\text { Poziom } 1 . \\
\text { „wymagający wsparcia” }\end{array}$ & $\begin{array}{l}\text { Bez wsparcia, deficyty w zakresie } \\
\text { komunikacji powodują zauważalne } \\
\text { problemy. Trudności w inicjowa- } \\
\text { niu interakcji społecznych. Obecne } \\
\text { sytuacje, w których odpowiedź na } \\
\text { starania innych osób jest dziwaczna lub } \\
\text { nieskuteczna. Możliwe zmniejszenie } \\
\text { zainteresowania interakcjami z innymi } \\
\text { ludźmi. Przykładowo: osoba zdolna do } \\
\text { wypowiadania się z użyciem pełnych } \\
\text { zdań, angażująca się w komunikację, } \\
\text { choć niezdolna do wzięcia udziału } \\
\text { we wzajemnej wymianie zdań. Próby } \\
\text { nawiązania znajomości są dziwaczne } \\
\text { i zwykle nieskuteczne. }\end{array}$ & $\begin{array}{l}\text { Sztywność wzorców ma } \\
\text { znaczny wpływ na funk- } \\
\text { cjonowanie w jednej lub } \\
\text { wielu sytuacjach. Trudności } \\
\text { w zmianie czynności na } \\
\text { inną. Problemy związane } \\
\text { z organizowaniem i pla- } \\
\text { nowaniem ograniczają } \\
\text { niezależność. }\end{array}$ \\
\hline
\end{tabular}

Tabela $2 \mathrm{c}$

\begin{abstract}
Procedury kodowania
W przypadku zaburzenia należącego do spektrum autyzmu, które jest związane ze znanym stanem ogólnomedycznym, genetycznym, czynnikiem środowiskowym lub z innym zaburzeniem neurorozwojowym, psychicznym lub zaburzeniem zachowania, należy stosować następujący zapis: zaburzenie należące do spektrum autyzmu związane z (nazwa stanu, zaburzenia lub czynnika) (np. zaburzenie należące do spektrum autyzmu z zespołem Retta). Ciężkość należy zapisywać na podstawie poziomu wsparcia, wymaganego w każdym z dwóch obszarów psychopatologicznych opisanych w tab. 2 (np. „wymagające bardzo znacznego wsparcia w obszarze deficytów w komunikacji oraz wymagające znacznego wsparcia z powodu ograniczonych, powtarzanych zachowań"). Następnie należy umieścić zapis dotyczący uszczegółowienia „Z współwystępującym upośledzeniem intelektualnym” lub „bez współwystępującego upośledzenia intelektualnego". Później zapisuje się uszczegółowienie dotyczące upośledzenia w zakresie funkcji językowych. Jeśli współwystępuje upośledzenie w zakresie językowym, należy odnotować aktualny stopień funkcjonowania w obszarze komunikacji werbalnej (np. „ze współwystępującym upośledzeniem językowym - mowa niezrozumiała” lub „ze współwystępującym upośledzeniem językowym - mowa zdaniami”). W przypadku występowania katatonii należy stosować osobny zapis: „katatonia związana z zaburzeniem ze spektrum autyzmu".
\end{abstract}

Źródło: opracował Tadeusz Pietras na podst. Gałecki, Święcicki (2015)

\title{
Koncepcja neuroróżnorodności w autyzmie
}

Przełomowym nurtem, który skierował dyskurs psychiatryczny na całkowicie nowe tory, okazała się być opracowana w latach 9o. XX wieku przez Judy Singer koncepcja neuroróżnorodności (Silberman 2017). Źródła swoistej optyki postrzegania zaburzeń neurorozwojowych upatrywać należy w oddolnej inicjatywie wysoko 
funkcjonujących osób ze spektrum autyzmu, postulujących zastąpienie kategorii „niepełnosprawności” pojęciem „inności” (Armstrong 2010). Harvey Blume (1998), dziennikarz, który w swoim artykule jako pierwszy użył słowa „neuroróżnorodność", konstatował, iż jest ona w takim samym stopniu kluczowa dla gatunku ludzkiego, jak bioróżnorodność dla życia w ogóle. Któż bowiem może określić, jaki sposób funkcjonowania i zasób predyspozycji okaże się najbardziej korzystny w danym momencie rozwoju cywilizacyjnego? Być może w dżungli skomputeryzowanej i zautomatyzowanej ponowoczesności najbardziej optymalny jest właśnie umysł autystyczny?

Koncepcja neuroróżnorodności osadzona jest w społecznym modelu niepełnosprawności, dostarczając równocześnie świeżego wglądu w podstawowe jego założenia. Idea neuroróżnorodności bowiem zakłada, iż neurologicznie atypowy (neurodywergentny) rozwój człowieka stanowi element normalnego zróżnicowania neurologicznego i jako taki powinien być w pełni akceptowany (Armstrong 2010). Można zatem zauważyć, iż koncepcja ta postuluje odejście od dychotomicznego podziału na to, co właściwe człowiekowi „normalnemu” oraz to, co stanowi o jego „anormalności”. Zamiast tego kwestia neurologicznego funkcjonowania człowieka rozważana jest w kategoriach wachlarza potencjalnych wzorców, które układają się w wielobarwną mozaikę dopełniających się i równowartościowych elementów. Jak zauważa Margaret Mead (1986), jeżeli pragniemy dążyć do wzbogacenia kultury/ cywilizacji, w której żyjemy, zobowiązani jesteśmy rozpoznawać pełną gamę potencjału możliwości ludzkich tak, aby zdolności każdej osoby odnalazły oczekującą na nie w społeczeństwie niszę.

Zgodnie z owym projektem intelektualnym, autyzm powinien być rozpatrywany nie jako zaburzenie, deficyt lub dysfunkcja, ale jako jeden z naturalnie występujących typów mechanizmów poznawczych, który charakteryzuje się szczególnymi zaletami, które w dziejach ludzkości przyczyniły się do rozwoju kultury i technologii. Przyjmując właściwą dla koncepcji neuroróżnorodności, w optyce należy zauważyć, iż trudności, jakich doświadczają osoby ze spektrum autyzmu, mają charakter kontekstualny. Egzystencja tychże osób osadzona jest bowiem w realiach społeczeństwa, konstruowanego w oparciu o to, co uznano za „normalne”, a zatem "neurotypowe” (Robertson 2010).

Charakterystyczna triada autystycznych zachowań nie stanowi jedynie specyficznych przejawów zaburzenia neurorozwojowego. Należy postrzegać je jako cechy, które w różnym natężeniu i konfiguracjach rozpowszechnione są w całej populacji. Współczesne kryteria diagnostyczne całościowych zaburzeń rozwoju podejmują próbę określenia momentu, w którym wskazane wyżej cechy przekraczają granice pewnej normy i stają się objawami zaburzenia. Zasadniczą kwestią, podnoszoną przez zwolenników idei neuroróżnorodności, jest sposób oraz zasadność wyznaczania owej normy, która stanowi przecież jedynie konstrukt kulturowo-społeczno-statystyczny, a nie granice istniejącą w sposób obiektywny. 
Opracowanie koncepcji neuroróżnorodności stało się detonatorem zmian społecznych, opartych na szybko rozwijającym się ruchu emancypacyjnym wysoko funkcjonujących osób ze spektrum autyzmu, walczących o własną podmiotowość. Zaangażowanie opierało się na założeniu, iż „Zachowania autystyczne najlepiej interpretują sami autystycy, a nie ich rodzice czy lekarze" (Silberman 2017, s. 23).

Ewa Furgał, selfadwokatka i działaczka antydyskryminacyjna ze spektrum autyzmu, definiuje etykietę nozologiczną przypisaną jej podczas diagnozy w nurcie neuroróżnorodności w następujący sposób: „Autyzm można zatem zdefiniować jako inny od neurotypowego rodzaju postrzegania i odbierania rzeczywistości, wynikający z różnic neurologicznych. Różnice te powodują u osób ze spektrum autyzmu m.in. trudności w interakcjach o charakterze społecznym i przeciążenia sensoryczne, natomiast u osób neurotypowych wywołują stereotypy i uprzedzenia wobec osób z autyzmem" (https://krytykapolityczna.pl/nauka/wlasnym-glosem-o-spektrum-autyzmu/, otwarty: 31.03.2020). Tego rodzaju optyka myślenia jest reprezentatywna dla szerokiego środowiska osób z wysoko funkcjonującym autyzmem.

Aktywiści starają się wyeliminować z dyskursu publicznego takie sformułowania, jak „chory na autyzm”, „cierpiący na autyzm”. Tego rodzaju frazeologizmy narzucają sposób interpretowania rzeczywistości, stanowiąc formę przemocy symbolicznej. Autystyczny model rozwoju sam w sobie nie powoduje cierpienia, w przeciwieństwie do społecznych reakcji w postaci niezrozumienia, ignorancji i wrogości. Reasumując, autyzm można rozumieć jako pewien styl funkcjonowania, który staje się „nieprawidłowością” dopiero za sprawą społecznej interpretacji.

W dalszej części niniejszej pracy rozpatrzony zostanie wpływ kształtującego się w ostatnich latach paradygmatu neuroróżnorodności na zakres i jakość autorstwa życia osób ze spektrum autyzmu.

\section{Koncepcja autorstwa życia osób ze spektrum autyzmu}

Konstrukt autorstwa własnego życia osób z niepełnosprawnością - opracowany przez Joannę Głodkowską - rozumieć należy jako „podmiotowy model afirmującego życia i optymalnego funkcjonowania, odnoszony do spełnianych przez tę osobę zadań rozwojowych i uzyskiwanego przez nią wsparcia społecznego" (Głodkowska 2015, s. 116).

Wśród konstytutywnych dla owej koncepcji ram teoretycznych wymienić należy:

- psychologię pozytywną;

- personalizm pedagogiczny;

- teorię optymalnego funkcjonowania;

- teorię zadań rozwojowych;

- teorię wsparcia społecznego (Głodkowska, Gosk 2018).

Horyzonty rozumienia konstruktu autorstwa życia osób z niepełnosprawnością zarysować można poprzez zaprezentowanie poszczególnych jego wymiarów, które odpowiadają kolejno wymienionym powyżej aspektom podbudowy teoretycznej: 
- eudajmonicznemu;

- personalistycznemu;

- funkcjonalnemu;

- temporalnemu;

- pomocowemu (Głodkowska 2014a).

Poprzez operacjonalizację poszczególnych wymiarów konstruktu wyróżnić można definiujące je kategorie. Dlatego też wymiar eudajmoniczny określany jest poprzez dobrostan i cnoty dobrego życia, wymiar personalistyczny jako podmiotowość osoby z niepełnosprawnością oraz nawiązywanie przez nią relacji dialogicznych, aspekt funkcjonalny poprzez kategorię jakości życia oraz samostanowienia. Wymiarowi temporalnemu odpowiada realizacja zadań adekwatnych do wieku życia, aspekt pomocowy natomiast określany jest poprzez strategie radzenia sobie w sytuacjach trudnych oraz przez wsparcie społeczne (Głodkowska 2014c).

W związku ze znaczącą rolą selfadwokatury osób ze zdiagnozowanymi całościowymi zaburzeniami rozwoju w konstruowaniu i popularyzowaniu owej optyki ontologicznej w poznawaniu autyzmu, najistotniejszym wymiarem wydaje się być aspekt personalistyczny (Głodkowska 2015). Podstawowym jego założeniem jest aksjomat głoszący, iż najwyższą wartością jest człowiek. Zatem osoba z niepełnosprawnością posiada zestaw niepowtarzalnych, unikatowych cech, które zapewniają jej prawo do bycia autorem własnego życia. Wyznacznikiem aspektu personalistycznego jest przede wszystkim podmiotowość, którą interpretować można dwutorowo: jako wynik oddziaływań społecznych lub w odniesieniu do własnych możliwości człowieka (Pągowska 2018). W obu przypadkach jednak konstytutywną, a zarazem finalną właściwością podmiotowości jest sprawczość i decyzyjność w nadawaniu kształtu własnemu życiu (Głodkowska 2014b).

Odejście od rozumienia spektrum autyzmu jako zaburzenia na rzecz perspektywy neuroróżnorodności wydobywa w pełni podmiotowość tychże osób. Diagnoza przestaje być stygmatyzującą etykietą, wyrzucającą osoby z autyzmem poza nawias społeczeństwa. Staje się wyznacznikiem pozytywnej tożsamości: tłumaczy przyczynę doświadczanych przez osobę trudności, zdejmując tym samym z barków bagaż lęku i poczucia winy. Antynomia wyrażająca się w pojęciach normalności $i$ anormalności traci swoje automatyczne przyporządkowanie aksjologiczne: normalny (neurotypowy) - wartościowy; anormalny (ze spektrum autyzmu) - niewartościowy. Skoro cechy autystyczne występują w całym społeczeństwie, a u osób $\mathrm{z}$ taką diagnozą wykazują jedynie wysokie nasilenie, opinii publicznej trudno jest zanegować prawo grupy do podmiotowości, gdyż wiązałoby się to w logiczny sposób z podważeniem własnej podmiotowości. Niwelowana jest zarazem granica społecznego dystansu wobec osób z autyzmem. „Anormalny” staje się „innym” w rozumieniu dialogicznym, a zatem „osobą na równi ze mną, ale różną ode mnie”.

Podobnego rodzaju impakt zaobserwować można w aspekcie eudajmonicznym (Głodkowska 2015). Perspektywa ta zwraca uwagę na poczucie szczęścia u osób $\mathrm{z}$ niepełnosprawnością, rozumianego w perspektywie arystotelesowskiej. Zgodnie 
z nim człowiek szczęśliwy pielęgnuje cnoty dobrego życia oraz realizuje wyznaczone sobie cele. Z poczuciem szczęścia związane jest bezpośrednio pojęcie osobistego rozkwitu, warunkowanego posiadaniem „cech zasadniczych” (pozytywne emocje, pochłonięcie czymś, posiadane zainteresowania, poczucie sensu i celowości) oraz „cech dodatkowych” (poczucie własnej wartości, optymizm, odporność, witalność, samostanowienie i pozytywne związki z innymi) (Seligman 2011, s. 47-48).

Należy zauważyć, iż koncepcja neuroróżnorodności w szczególny sposób akcentuje wartości i zasoby osób ze spektrum autyzmu. Z tej perspektywy autyzm, jako naturalnie występujący typ mechanizmów poznawczych, cechuje się konkretnymi zaletami, które przyczyniły się do rozwoju technologii i kultury. Współcześnie zwraca się szczególną uwagę na przypadki sawantów, a poszukiwanie cech z obszaru autystycznej triady u znanych powszechnie ludzi nauki i sektora technologicznego stało się interesującą rozrywką intelektualną. Bezsprzecznie opinię publiczną coraz bardziej fascynują niezwykłe wewnętrzne zasoby osób ze spektrum autyzmu. Dzięki ruchom emancypacyjnym społeczeństwo zaczyna rozumieć, iż kompetencje interpersonalne nie są wartością ani nadrzędną, ani też konieczną dla bycia wspaniałym człowiekiem. Fakt ten ma swoje bezpośrednie przełożenie na aspekt poczucia własnej wartości u osób ze spektrum autyzmu. Zyskują one adekwatne poczucie własnej wartości, tryskają optymizmem i wykazują szereg pozytywnych emocji. Koncepcja neuroróżnorodności wskazuje im, iż nie są ludźmi gorszymi i niepełnowartościowymi niż inni, jeśli chodzi o wewnętrzne zasoby, a jedynie odmiennymi, którzy dzięki swoim możliwościom mogą realizować inne, lecz niemniej wartościowe i społecznie niezbędne zadania. Silberman (2017) wskazuje nawet, iż to osoby ze spektrum autyzmu, dzięki poznawczej nieszablonowości, wyznaczają kierunek rozwoju cywilizacyjnego.

W aspekcie funkcjonalnym należy podkreślić właśnie komponent kompetencji i zdolności adaptacyjnych u osób z autyzmem, uwidaczniany przez koncepcję neuroróżnorodności. Osoba z całościowymi zaburzeniami rozwoju przestaje być postrzegana jako dotknięta osobistą tragedią, ponieważ mimo trudności społecznych posiada szereg unikatowych kompetencji, które niejako na zasadzie zdolności o charakterze kompensacyjnym umożliwiają jej w pełni samodzielne funkcjonowanie.

Koncepcja neuroróżnorodności ma również zasadniczy wpływ na aspekt temporalny konstruktu autorstwa życia (Głodkowska 2015). Realizowanie zadań charakterystycznych i normalnych dla kolejnych etapów życia (np. podjęcie satysfakcjonującego zatrudnienia, założenie rodziny itp.) może być dla osób z autyzmem o wiele łatwiejsze i społecznie bardziej dostępne dzięki poczuciu, iż osoby te są odmienne, lecz równie wartościowe, a zatem mają prawo do tych samych życiowych doświadczeń. Czym innym jest bowiem pakiet praw przyznawanych im przez Konstytucję RP, a czym innym społeczne przyzwolenie i wewnętrzne poczucie bycia w mocy do zrealizowania pewnych celów i bycia w prawie do autorskiego ich wyznaczenia. 
Najmniej wyraźny impakt idei neuroróżnorodności zaobserwować można w aspekcie pomocowym. Należy jednak przyznać, iż wzmocnione poczucie własnej wartości, kompetencji i sprawczości, będące efektem postrzegania siebie jako osoby o odmiennym typie funkcjonowania poznawczego, a nie zaburzonej, skutkować może wydajniejszym radzeniem sobie w trudnych sytuacjach. Wiążąca się z tym zmiana społecznej percepcji tychże osób rzutować może na zakres i rodzaj udzielanego im wsparcia, przy rezygnacji z pomagania im na rzecz budowania psychologicznego rusztowania (Schaffer 2009).

\section{Podsumowanie}

Przy wkomponowywaniu koncepcji neuroróżnorodności w poszczególne wymiary konstruktu autorstwa własnego życia u osób z autyzmem zauważyć można szczególną potrzebę zaakcentowania istnienia „autystycznej tożsamości” (Ortega 2009) w obliczu kultury skoncentrowanej na „normalności”. Pojęcie neuroróżnorodności staje się swoistym paradygmatem rozumienia nieuchwytnego fenomenu, jakim jest autyzm. Stanowi tym samym kluczowy fundament dla budowania silnej pozycji osób z diagnozą ASD jako autorów własnego życia w zastanej przez nich rzeczywistości społecznej, której nieadekwatność nosi znamiona niemal symbolicznej przemocy.

\section{Bibliografia}

Armstrong T. (2010). Neurodiversity. Discovering the extraordinary gifts of autism, $A D H D$, dyslexia and other brain differences. Cambridge: Da Capo Press.

Blume H. (1998). Neurodiversity. On the neurological underpinnings of geekdom, dostępny na:https://www.theatlantic.com/magazine/archive/1998/o9/neurodiversity/305909/ (otwarty: 31.03.2020).

Głodkowska J. (2014a). Autorstwo życia a niepełnosprawność - ponawiane odczytywanie idei normalizacji. „Człowiek-Niepełnosprawność-Społeczeństwo”, $1(23)$, s. 75-97.

Głodkowska J. (2014b). Rozważania nad podmiotowościa a niepełnosprawność $u$ źródeł współczesnego ujęcia $i$ w perspektywie interdyscyplinarnej. „CzłowiekNiepełnosprawność-Społeczeństwo”, 2(24), s. 91-109.

Głodkowska J. (2014c). Być podmiotem i stawać się autorem swojego życia - paradygmat wsparcia $w$ przygotowaniu osób z niepetnosprawnościa do budowania własnej tożsamości i wzbogacania dobrostanu. „Człowiek-NiepełnosprawnośćSpołeczeństwo", 4(26), s. 29-44.

Głodkowska J. (2015). Autorstwo własnego życia osoby z niepełnosprawnościa - konceptualizacja w perspektywie dobrostanu, podmiotowości, optymalnego funkcjonowania $i$ wsparcia. W: Personalistyczne ujęcie fenomenu niepełnosprawności. Głodkowska J. (red.). Warszawa: Wydawnictwo APS, s. 110-134. 
Głodkowska J., Gosk U. (2018). Autorstwo własnego życia osoby z niepełnosprawnością (AWŻ-OzN) - od źródeł i konstruktu teoretycznego do projektowania etapów i procedur badawczych. W: Tradycja i współczesność pedagogiki specjalnej w tworzeniu społeczeństwa dla wszystkich. Głodkowska, J., Sipowicz, K., PatejukMazurek, I. (red.). Warszawa: Wydawnictwo APS, s. 500-518.

Grandin T. (2017). Mózg autystyczny. Podróż w głąb niezwykłych umysłów. Kraków: Copernicus Center.

Krause A. (2010). Współczesne paradygmaty pedagogiki specjalnej. Kraków: Oficyna Wydawnicza „Impuls”.

Kryteria diagnostyczne DSM-5. (2015). Gałecki P., Święcicki Ł. (red.) Wrocław: Edra Urban \& Partner.

Mead M. (1986). Trzy studia. Dojrzewanie na Samoa. Dorastanie na Nowej Gwinei. Płeć $i$ charakter $w$ trzech społecznościach pierwotnych. Warszawa: Państwowy Instytut Wydawniczy.

Ortega F. (2009). The cerebral subject and the challenge of neurodiversity. „BioSocieties”, 4(4), s. 425-445.

Pągowska M. (2018). Paradygmat podmiotowości w pedagogice specjalnej-rozważania $w$ kontekście autonomii, samostanowienia $i$ autorskiego życia osób z niepetnosprawnością. W: Tradycja i współczesność pedagogiki specjalnej w tworzeniu społeczeństwa dla wszystkich. Głodkowska, J., Sipowicz, K., Patejuk-Mazurek, I. (red.). Warszawa: Wydawnictwo APS , s. 451-468.

Pisula E. (2018). Autyzm. Przyczyny, symptomy, terapia. Gdańsk: Wydawnictwo Harmonia.

Rajewski A. (2011). Całościowe zaburzenia rozwojowe. W: Psychiatria. T. 2. Pużyński S., Rybakowski J., Wciórka J. (red.). Wrocław: Edra Urban \& Partner, s. 591-598.

Robertson S.M. (2010). Neurodiversity, quality of life and autistic adults: shifting research and professional focuses onto real-life challenges. „Disability Studies Quarterly”, 30(1), dostępny na: https://dsq-sds.org/article/view/1069/1234 (otwarty: 31.03.2020).

Schaffer H.R. (2009). Psychologia dziecka. Warszawa: Wydawnictwo Naukowe PWN.

Silberman S. (2017). Neuroplemiona. Dziedzictwo autyzmu i przyszłość neuroróżnorodności. Białystok: Wydawnictwo Vivante.

Sipowicz K., Pietras T. (2017). Wprowadzenie do pedagogiki inkluzyjnej (włączającej). Wrocław: Wydawnictwo Continuo.

Verhoeff B. (2012). What is thing called autism? A critical analysis of the tenacious search for autism's essence. „Biosocieties”, 7(4), s. 410-432.

Wujcik R., Porzycka A., Witusik A., Pietras T. (2010). Neurorozwojowa hipoteza autyzmu. W: Autyzm - epidemiologia, diagnoza i terapia. Pietras T., Witusik A., Gałecki, P. (red.). Wrocław: Wydawnictwo Continuo, s. 31-74. 


\title{
Zasoby internetowe
}

https://krytykapolityczna.pl/nauka/wlasnym-glosem-o-spektrum-autyzmu/ (otwarty: 30.03.2020).

\section{THE IMPORTANCE OF THE CONCEPT OF NEURO-DIVERSITY FOR THE AUTHORSHIP OF THE LIVES OF PEOPLE WITH AUTISM SPECTRUM}

\begin{abstract}
The subject of the study is the reflection on the phenomenon of neuro-diversity in people with ASD spectrum in the context of the concept of their own life authorship. Neuro-diversity means population differentiation of properties of the central nervous system which translates into cognitive and emotional differentiation of the population. The aim of the study is to review the literature on the relationship between authorship of one's own life, neuro-diversity and ASD spectrum disorders. The method used in this study is a literature review with special emphasis on Polish literature. The clinical picture of ASD spectrum is diverse. Among people with ASD there are both independent and those requiring 24-hour supervision. People with autism are said to be well and badly functioning. High-functioning individuals with autism are capable of self-determination as opposed to those with more severe autism who require care and community support. Among people with ASD, there is a large neuro-diverse clinical picture. A large proportion of people are capable of self-determination and of creating their own lives.
\end{abstract}

Keywords: autism; neurodiversity; authorship of one's own life by people with disabilities. 